Available Online : https://proceeding.researchsynergypress.com/index.php/cset/index

RSF Conference Series: Engineering and Technology

ISSN 2809-6843 (Online) | 2809-6878 (Print)

Volume 1 Number 1 (2021): 388-393

\title{
Improvement of Online Journal System (OJS) Information to Optimize Journal Accreditation Score
}

\section{Ayu Utami1*, Titi Tiara Anasstasia1, Johan Danu Prasetya1, Wisnu Aji Dwi Kristanto1, Fandinata Amrizal1}

\author{
1 Department of Environmental Engineering, UPN “Veteran” Yogyakarta, Indonesia
}

\begin{abstract}
Scientific journal is an indicator of the progress of an educational institution. Publication in Scientific Journals is a tool to build the reputation of lecturers, researchers, teachers, and universities. However, the management of journals in Indonesia still does not consider the importance of indexing as a way of global dissemination. This is evident from the data showing that of the total journals registered in Indonesia, only 5.17\% have been accredited. Department of Environmental Engineering, Faculty of Mineral Technology, UPN "Veteran" Yogyakarta has a Scientific Journal called Jurnal Ilmiah Lingkungan Kebumian (JILK). JILK is a forum for writing, scientific work, and research related to the environmental management of the mining industry, environmental management of petroleum and geothermal industry, regional development and disaster mitigation and relevant fields of environmental science and technology studies. Journal accreditation can expand JILK connectivity to improve the quality of publications. The main objectives of this research are to optimize and improve the management of JILK to get maximum accreditation score. There are several steps to conduct this research including identification of the requirement for journal accreditation, preliminary assessment, evaluation of journal management, workshop and benchmarking, implementation of evaluation results, and submit the journal accreditation. The methodology that used for this research are discussion with journal expert and benchmarking with another scientific journal. From the implementation of preliminary assessment from internal editorial team and evaluation from external journal expert, JILK can increase the accreditation score from 59 to 67.
\end{abstract}

Keywords: accreditation, assessment, journal, management, OJS

\section{INTRODUCTION}

This is an open access article under the CC-BY-NC license

Scientific journal is an indicator of the progress of an educational institution. Publication in Scientific Journals is a tool to build the reputation of lecturers, researchers, teachers, and universities. Graduation of master's and doctoral students also requires the same thing. A citation journal article means that it contains scientifically viable content as a source of scientific development truth. Authors of journals whose scientific work is widely imitated will also get a high h-index as evidence of the academic world's recognition of its existence and quality. However, the management of journals in Indonesia still does not consider the importance of indexing as a way of global dissemination (Direktorat Jenderal Penguatan Riset dan Pengembangan, 2018). This is evident from the data showing that of the total journals registered in Indonesia, only 5.17\% have been accredited (Nashihuddin and Aulianto, 2016).

Department of Environmental Engineering, Faculty of Mineral Technology, UPN "Veteran" Yogyakarta has a Scientific Journal called Jurnal Ilmiah Lingkungan Kebumian (JILK). This journal began to be published in print in July 2015 initiated by the Chief of the Department at that time. JILK is a forum for writing, scientific work, and research related to the environmental management of the mining industry, environmental management of petroleum and geothermal industry, regional development and disaster mitigation and relevant fields of environmental science and technology studies.

Journal accreditation is a form of official recognition of the quality assurance of scientific journals through fairness assessment activities of manuscript screening, feasibility of management, and timeliness of publication of the journal. Journal accreditation can expand JILK connectivity to improve the quality of publications.

Journal management in order to be accredited can be achieved in various ways, such as participating in various activities regarding OJS training, Digital Object Identifier (DOI) training, journal indexation, 
management in publishing, activeness of journal managers, journal accreditation assistance, and following grants in journal management (Junandi, 2018).

The main objectives of this research are to optimize and improve the management of JILK to get maximum accreditation score. The results of this activity can be used as a basis in improving the management of the journal before applying for national accreditation.

\section{LITERATURE REVIEW}

\section{A. Journal Management}

There are five main problems faced by journal managers in Indonesia that cannot be recorded in reputable indexers, among others (Junandi, 2018):

a) Visibility and accessibility of scientific journals is not good because they have not implemented the management of scientific journals online (online);

b) The process of managing the article has not implemented the standard of scientificarticles;

c) The quality of the publication of scientific journals is still mostly not good;

d) Quality control of scientific journals through the process of review by bestari partners and the utilization of the selingkung style has not been consistent; and/or

e) The quality of the substance of the article has not been maintained and maintainedproperly.

To improve quality in the journal publishing system, the implementation of the electronic publishing system using a well-managed Open Journal System (OJS) is one of the solutions that can be applied. The main thing of the operational standards in OJS is the determination of journal team such as journal managers, editors, authors, and reviewers who are managed systematically and can be accessed online (Amrizal, 2018).

\section{Journal Accreditation}

Competition in market for journal subscriptions is one of the issues that motivate the academic journals, sponsoring organizations, and journal editors improve their quality. Beside the economic issue from marketing, the journals want to publish articles that have more impact for extending and expanding knowledge. Ranking journals and also accreditation provides an objective means for self-evaluation (Tahai and Meyer, 1997).

In 2011, scientific periodicals can be accredited if they meet the conditions stipulated in the Regulation of the Minister of National Education (PERMENDIKNAS) sbb (Permendiknas, 2011):

1) Contains articles that clearly advance knowledge, science, technology, and/or art based on research and study results that contain original and plagiarism-free findings and/orthoughts;

2) Have a reputable editorial board or editor representing the fields of knowledge, science, technology, and/or art;

3) Involving independent partners from various universities and/or research and development bodies and different industries from within and/or abroad that screen manuscripts anonymously;

4) Written in Indonesian and/or the official language of the United Nations;

5) Maintaining the correctness of the writing style and the format of its appearance;

6) Published in print and electronically through information and communication technology networks; and

7) Keep the schedule in time.

In 2018, the accreditation of scientific journals is re-regulated in the Regulation of the Minister of Research, Technology, and Higher Education of the Republic of Indonesia Number 9 of 2018 on Accreditation of Scientific Journals. In the regulation, accreditation of scientific journals consists of eight elements of assessment, which is the criteria for determining the ranking and accreditation status of a scientific journal including (Permenristekdikti, 2018):

a) Journal title;

b) Publisher organizationKelembagaan penerbit;

c) Editorial and journal management;

d) Article substantial;

e) Writing style;

f) Appearance. 
Improvement of Online Journal System (OJS) Information to Optimize Journal Accreditation Score Ayu Utami, Titi Tiara Anasstasia, Johan Danu Prasetya, Wisnu Aji Dwi Kristanto, Fandinata Amrizal

g) Continuity; and

h) Distribution.

There are 6 level of accreditation score for national journal accreditation ranking. Below the score range that determine the level of journal.
a) Accredited Level 1 (Satu) $85 \leq \mathrm{n} \leq 100$
b) Accredited Level 2 (Dua) $70 \leq \mathrm{n}<85$
c) Accredited Level 3 (Tiga) $60 \leq n<70$
d) Accredited Level 4 (Empat) $50 \leq \mathrm{n}<60$
e) Accredited Level 5 (Lima) $40 \leq n<50$
f) Accredited Level 6 (Enam) $30 \leq \mathrm{n}<40$

\section{RESEARCH METHODOLOGY}

There are several steps to conduct this research including identification of the requirement for journal accreditation, preliminary assessment, evaluation of journal management, workshop and benchmarking, implementation of evaluation results, and submit the journal accreditation. The methodology that used for this research are discussion with journal expert and benchmarking with another scientific journal.

Preliminary assessment was conduct by discussion with internal editorial team. Internal editorial team grading and assess the existing condition of the journal. Grading and assessment based on Journal Accreditation Guideline from the Minister of Research, Technology, and Higher Education of the Republic of Indonesia. Evaluation of journal management was conducted by internal editorial team and journal expert. Benchmarking with another highest-ranking scientific journal was obtained to improve the journal management.

Implementation of evaluation also done by discussion. The internal editorial team implement the evaluation by online and based on the suggestion from journal expert. After the implementation, the journal expert doing an assessment together with the internal editors and discuss about the grade of the journal. Furthermore, when the grade is approved by the journal expert and internal editors, the internal editors submit journal accreditation form to the online system.

\section{FINDING AND DISCUSSION}

\section{B. Preliminary Assessment}

Preliminary Assessment was done by discussion between internal editorial team and journal expert. Before discussed the assessment with the expert, editorial team try to grade the existing condition of the journal. The results from the discussion are identification and mapping the journal obstacle, preliminary assessment of accreditation form, and determination of the priority scale of completion. Besides that, the journal expert also analyzes the OJS of JILK. The result of preliminary assessment can be seen at Table 1.

Table 1. Editorial Team Assessment Result

\begin{tabular}{|c|c|c|c|}
\hline \multirow{2}{*}{ No } & Indicator & \multicolumn{2}{|c|}{ Scoring } \\
\cline { 3 - 4 } & Journal title & Management & Substantial \\
\hline 1 & Publisher organization & 3 & - \\
\hline 2 & Editorial and journal management & 14 & - \\
\hline 3 & Article substantial & - & - \\
\hline 4 & Writing style & - & 19 \\
\hline 5 & Appearance & 7 & - \\
\hline 6 & Continuity & 4 & - \\
\hline 7 & Distribution & 5 & - \\
\hline 8 & Total & $\mathbf{3 5}$ & $\mathbf{2 9}$ \\
\hline \multicolumn{2}{|c|}{} \\
\hline \multicolumn{2}{|c|}{ Grading Estimation } & $\mathbf{3 9}$ \\
\hline
\end{tabular}

Based on the indicator from journal accreditation guideline, the total grading estimation from preliminary assessment is 59. This grade means that JILK is at level 4 of national journal ranking. Preliminary 
assessment found that JILK have weakness on article substantial and distribution. Thus, the editorial team will discuss this finding with the journal expert.

From the journal expert, the results of identification and assessment are the guidelines improvement, journal history, review form, updating articles in the google scholar, and activativation of DOI. Furthermore, the expert also suggests editorial team to revise their manuscript template and improve the article quality for the next publication issue.

\section{Evaluation}

The journal expert recommends and help the editorial team to improve the OJS appearance. Improving OJS appearance can help the accreditation assessor to assess the journal. From the Fugure 1 can be seen the difference of OJS appearance.

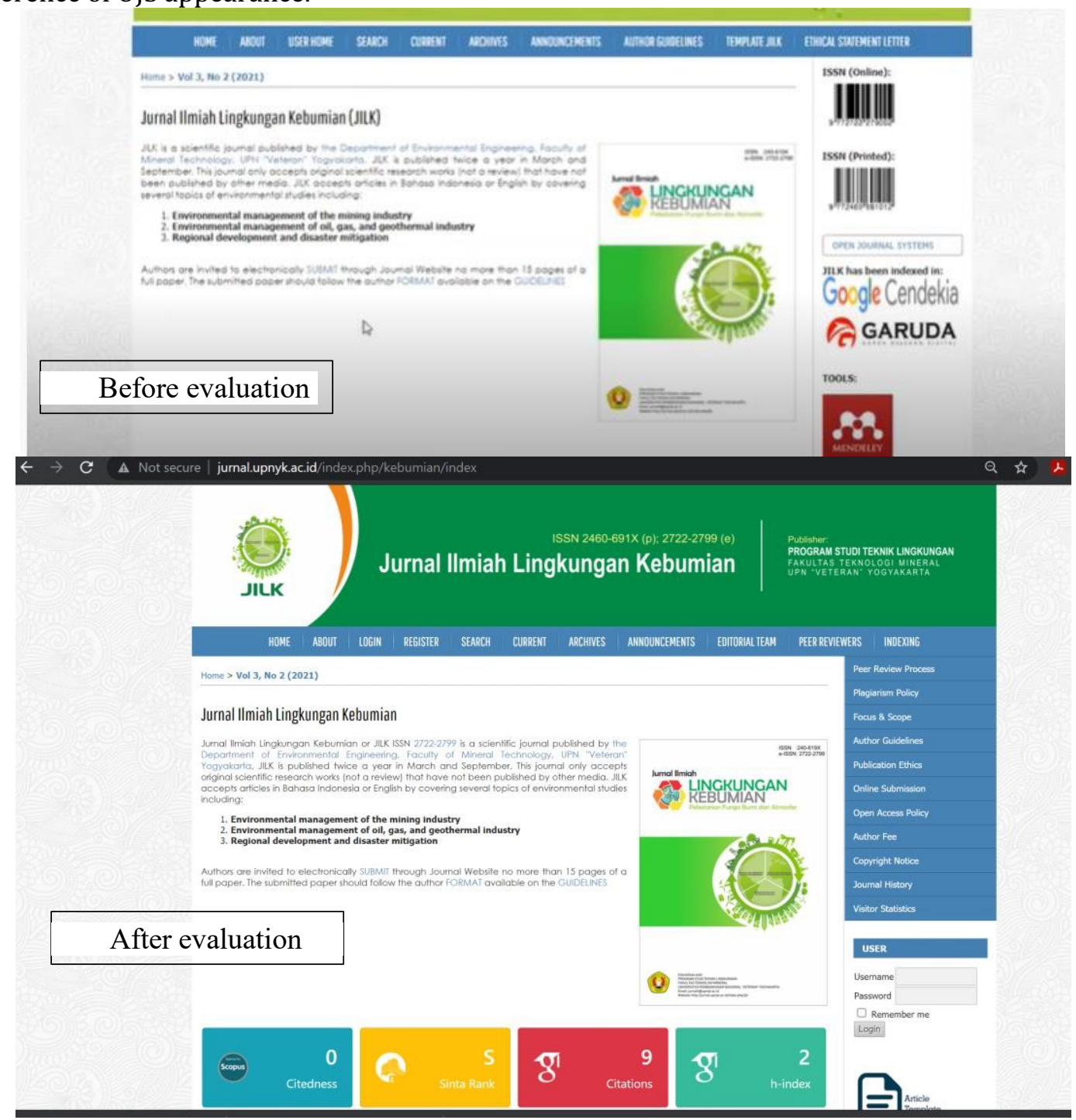

Figure 1. Improving 0JS Appearance and Management

Implementation of evaluation was done by editorial team with improvement of journal template, adding journal history, and adding the guideline for reviewers and editors. Table 2 shows journal history that is added to the system.

Table 2. Journal History of JILK

\begin{tabular}{|c|l|l|}
\hline No & Year & \multicolumn{1}{c|}{ History } \\
\hline 1 & 2015 & First print version of the journal \\
\cline { 3 - 3 } & & Submission of ISSN print version \\
\cline { 3 - 3 } & & $\begin{array}{l}\text { Begin to collarate with internal reviewer for } \\
\text { publishing }\end{array}$ \\
\hline
\end{tabular}


RSF Conference Series: Engineering and Technology

Vol 1 (1), 388-393

Improvement of Online Journal System (OJS) Information to Optimize Journal Accreditation Score Ayu Utami, Titi Tiara Anasstasia, Johan Danu Prasetya, Wisnu Aji Dwi Kristanto, Fandinata Amrizal

\begin{tabular}{|c|c|c|}
\hline No & Year & History \\
\hline & & Start on using Online Journal System (OJS) \\
\hline \multirow[t]{2}{*}{2.} & \multirow[t]{2}{*}{2019} & Plagiarism and grammar check for the first time \\
\hline & & $\begin{array}{l}\text { The first issue of the Online JILK. The JILK start to } \\
\text { published periodically twice a year every March and } \\
\text { September. }\end{array}$ \\
\hline 3. & 2020 & $\begin{array}{ll}\text { - } & \text { ISSN submission online JILK. } \\
\text { - } & \text { JILK registered with GARUDA: Garba Digital } \\
& \text { Reference } \\
\text { - } & \text { JILK listed on Google Scholar indexation } \\
\text { - } & \text { Install DOI on each issue } \\
\text { - } & \text { Increase external partners to } 15 \text { people } \\
\text { - } & \text { Issued a total of } 6 \text { publications in } 3 \text { Volumes as of } \\
& \text { March } 2021 \\
\text { - } & \text { Add flag counter and Mendeley tools }\end{array}$ \\
\hline 4. & 2021 & $\begin{array}{l}\text { Improve the substance of the article through } \\
\text { improvements in the writing format } \\
\text { - } \\
\text { - Apply for DOAJ indexation } \\
\text { Apply for accreditation of the Scientific Journal } \\
\text { of the Earth Environment }\end{array}$ \\
\hline
\end{tabular}

Visitor of website also should be increasing. Thus, editorial team build up strategy to increase the OJS visitors. On July, the visitors of OJS starts to significantly increase. The increasing of OJS visitors can be seen at Figure 2.

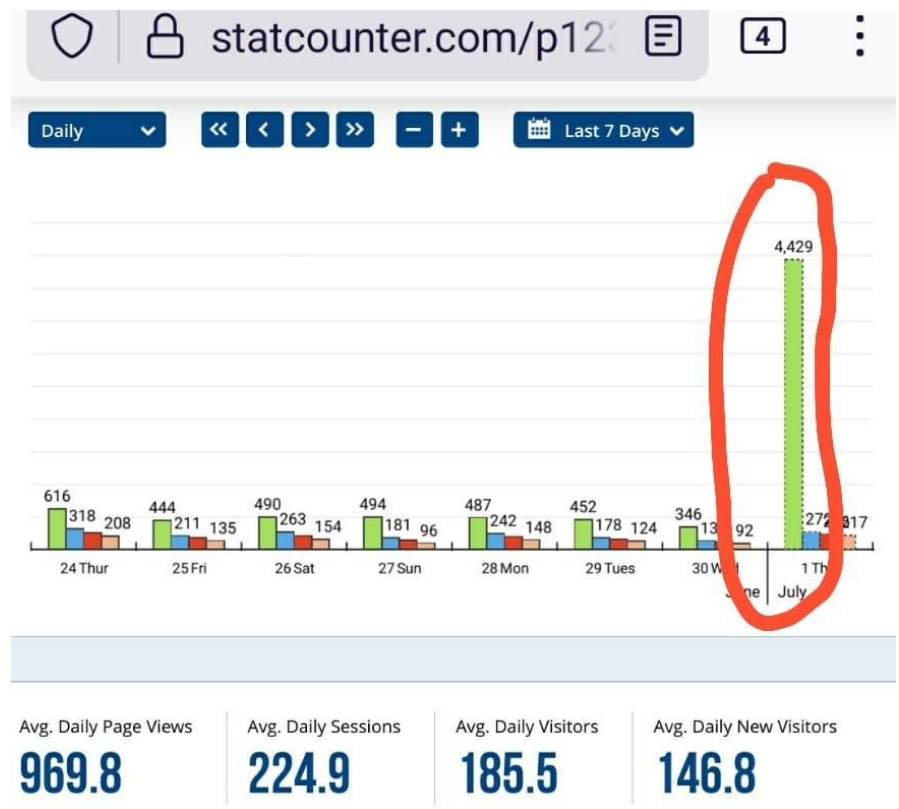

\begin{tabular}{lrcc} 
& Page Views & Sessions & Vis \\
\hline Thur, 1 July 2021 & 4,429 & 272 \\
\hline Wed, 30 June 2021 & 346 & 134 \\
\hline Tues, 29 June 2021 & 452 & 178 \\
\hline Mon, 28 June 2021 & 487 & 242 \\
\hline Sun, 27 June 2021 & 494 & 181 \\
\hline Sat, 26 June 2021 & 490 & 263 \\
\hline Fri, 25 June 2021 & 444 & 211 \\
\hline Thur, 24 June 2021 & 616 & 318 \\
\hline Total & $\mathbf{7 , 7 5 8}$ & $\mathbf{1 , 7 9 9}$
\end{tabular}


Figure 2. 0JS Statcounter in the Early July

\section{Final Assessment}

Improvement from editorial team and external journal expert can increase the accreditation score from 59 to 67. For the final assessment, updating data for entire journal management information. Final assessment before submitting the accreditation form, editorial team complete the information about editors, reviewers, and editorial team publication on OJS.

Contuinity of management system of journal should be managed by writing JILK management guidelines book. From this book, the next editorial team can keep up a better management system. The improvement of information, implementation of evaluation, and discussion with the expert is the method of editorial team to optimize accreditation score. With the recent score, JILK can obtain level 3 of National Journal Accreditation Ranking System.

\section{CONCLUSION AND FURTHER RESEARCH}

From the implementation of preliminary assessment from internal editorial team and evaluation from external journal expert, JILK can increase the accreditation score from 59 to 67. Optimization of OJS content such as article management system, completing editorial team information, and modifications of OJS layout can increase the score and level of national journal accreditation.

\section{REFERENCES}

Amrizal, A. (2018) 'Pemanfaatan Open Jurnal System (OJS) Untuk Pengelolaan Jurnal Lumbung di Politeknik Pertanian Negeri Payakumbuh', Lumbung, 17(2), pp. 64-74. doi: 10.32530/lumbung.v17i2.36.

Direktorat Jenderal Penguatan Riset dan Pengembangan, K. R. T. dan P. T. (2018) Pedoman Akreditasi Jurnal Ilmiah 2018. Jakarta: Direktorat Pengembangan, Direktorat Jenderal Penguatan Riset dan Kementerian Riset, Teknologi, dan Pendidikan Tinggi.

Junandi, S. (2018) 'Pengelolaan Jurnal Elektronik Bidang Perpustakaan Menuju Jurnal Terakreditasi', Pustabiblia: Journal of Library and Information Science, 2(1), p. 119. doi: 10.18326/pustabiblia.v2i1.119-136.

Nashihuddin, W. and Aulianto, D. R. (2016) 'Pengelolaan Terbitan Berkala Ilmiah Sesuai Ketentuan Akreditasi: Upaya Menuju Jurnal Trakreditasi Dan Bereputasi Internasional', Jurnal Pustakawan Indonesia, 15(1-2), pp. 83-98.

Permendiknas (2011) 'Peraturan Menteri Pendidikan Nasional Republik Indonesia Nomor 22 Tahun 2011 tentang Terbitan Berkala Ilmiah'.

Permenristekdikti (2018) 'Peraturan Menteri Riset, Teknologi dan Pendidikan Tinggi Nomor 9 Tahun 2018 Tentang Akreditasi Jurnal Ilmiah', Direktorat Jenderal Penguatan Riset dan Pengembangan, (428), pp. 1-9.

Tahai, A. and Meyer, M. J. (1997) 'Revealed preference study of management journals' direct influences', Proceedings - Annual Meeting of the Decision Sciences Institute, 2(March 1998), pp. 1006-1008. doi: 10.1002/(sici)1097-0266(199903)20:3<279::aid-smj33>3.3.co;2-u. 